\title{
Antifungal Activity of Maytenin and Pristimerin
}

\author{
Fernanda P. Gullo, ${ }^{1}$ Janaina C. O. Sardi, ${ }^{1}$ Vânia A. F. F. M. Santos, ${ }^{2}$ \\ Fernanda Sangalli-Leite, ${ }^{1}$ Nayla S. Pitangui, ${ }^{1}$ Suélen A. Rossi, ${ }^{1}$ \\ Ana C. A. de Paula e Silva, ${ }^{1}$ Luciana A. Soares, ${ }^{1}$ Julhiany F. Silva, ${ }^{1}$ \\ Haroldo C. Oliveira, ${ }^{1}$ Maysa Furlan, ${ }^{2}$ Dulce H. S. Silva, ${ }^{2}$ Vanderlan S. Bolzani, ${ }^{2}$ \\ Maria José S. Mendes-Giannini, ${ }^{1}$ and Ana Marisa Fusco-Almeida ${ }^{1}$ \\ ${ }^{1}$ Laboratory of Clinical Mycology, Department of Clinical Analysis, Faculty of Pharmaceutical Sciences, UNESP,
Rua Expedicionários do Brasil 1621, 14801-902 Araraquara, SP, Brazil
${ }^{2}$ Institute of Chemistry, UNESP, Rua Professor Francisco Degni 55, 14800-900 Araraquara, SP, Brazil
}

Correspondence should be addressed to Ana Marisa Fusco-Almeida, ana.marisa@uol.com.br

Received 5 January 2012; Revised 17 February 2012; Accepted 23 March 2012

Academic Editor: Guillermo Schmeda-Hirschmann

Copyright (C) 2012 Fernanda P. Gullo et al. This is an open access article distributed under the Creative Commons Attribution License, which permits unrestricted use, distribution, and reproduction in any medium, provided the original work is properly cited.

\begin{abstract}
Fungal infections in humans have increased alarmingly in recent years, particularly in immunocompromised individuals. Among the infections systemic candidiasis, aspergillosis, cryptococcosis, paracoccidioidomycosis, and histoplasmosis mortality are more prevalent and more severe in humans. The current high incidence of dermatophytosis is in humans, especially as the main etiologic agents Trichophyton rubrum and Trichophyton mentagrophytes. Molecules pristimerin and maytenin obtained from the plant Maytenus ilicifolia (Celastraceae) are known to show various pharmacological activities. This study aimed to evaluate the spectrum of antifungal activity of maytenin and pristimerin and their cytotoxicity in human keratinocytes (NOK cells of the oral mucosa). It was concluded that the best spectrum of antifungal activity has been shown to maytenin with MIC varying from 0.12 to $125 \mathrm{mg} / \mathrm{L}$, although it is also active with pristimerin MIC ranging between 0.12 and $250 \mathrm{mg} / \mathrm{L}$. Regarding the toxicity, both showed to have high $\mathrm{IC}_{50}$. The SI showed high pristimerin against some species of fungi, but SI maytenin was above 1.0 for all fungi tested, showing a selective action of fungi. However, when comparing the two substances, maytenin also showed better results. The two molecules can be a possible prototype with a broad spectrum of action for the development of new antifungal agents.
\end{abstract}

\section{Introduction}

Fungal infections are mainly caused by opportunistic fungi and are usually associated with immunosuppression [1]. Over the past two decades, invasive fungal infections have emerged as a major threat to immunocompromised patients, since species of Aspergillus, Candida, Cryptococcus, and Histoplasma emerging pathogens such as Fusarium and Trichophyton can cause infection when defenses of host are broken [1]. Paracoccidioidomycosis is a fungal infection that is very important, which affects a large percentage of the rural population of Latin America [2].

There is now a great interest in the discovery of new molecules of natural origin for the treatment of various diseases [3]. Natural products have provided a wide variety of drugs and have become an alternative to large demand for new antifungal drugs [4]. In Brazil, the use of medicinal plants in traditional medicine has increased considerably in recent years. The wide distribution of natural resources in Brazilian ecosystems and natural diversity of chemical components and provides the country with potential bioactive materials [5].

Maytenus ilicifolia (Celastraceae), popularly known as "espinheira santa," has been used in traditional medicine since the mid-1920s [6]. The secondary metabolites, maytenin and pristimerin (Figure 1), are classified as quinonemethide triterpenoids and mainly isolated from the bark of the roots of mature M. ilicifolia plants [7]. Several studies have shown that maytenin exhibits strong antimicrobial activity against Gram-positive and Gramnegative organisms, but there are no studies detailing the effects of these substances on fungi [8]. 


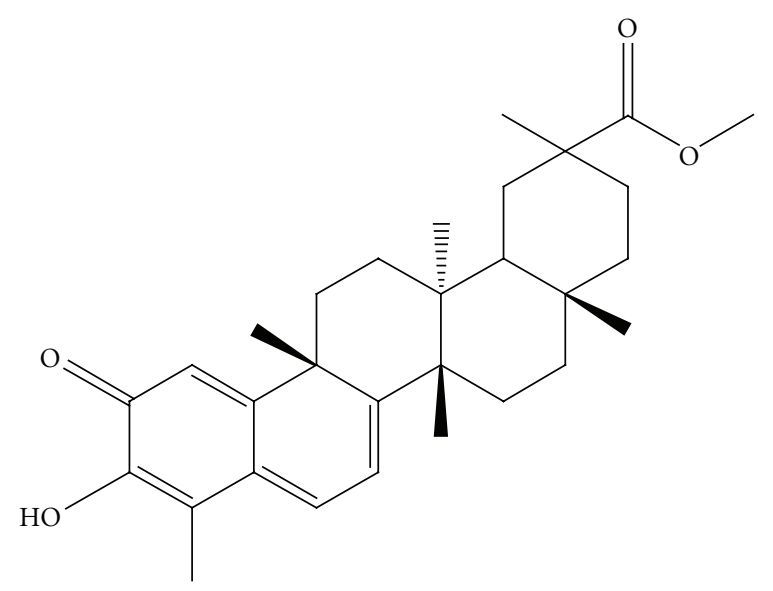

Pristimerin (1)

(a)

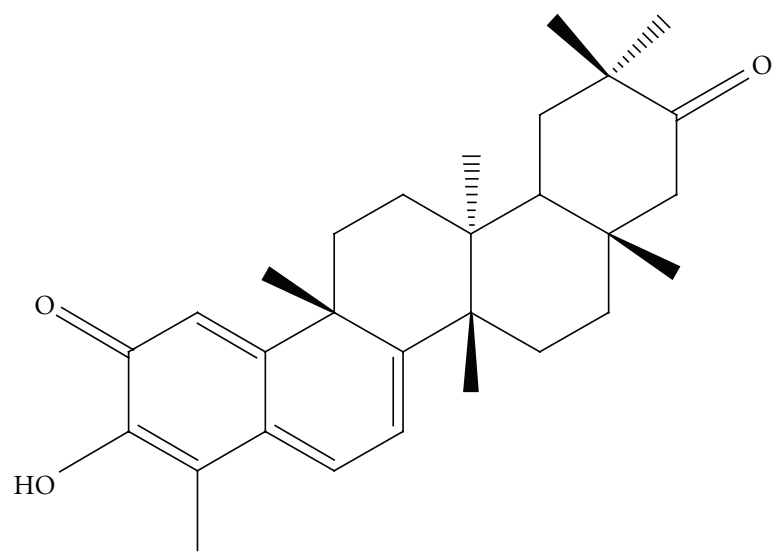

Maytenin (2)

(b)

FIGURE 1: Structures of the isolated quinonemethide triterpenes from M. ilicifolia, pristimerin (1) and maytenin (2).

The need to discover new antifungal molecules and natural products is of great importance for the development of new therapeutic tools. This paper proposes the study of the potential antifungal potential of maytenin and pristimerin against fungi, an agent of important mycoses. The potential broad spectrum of these molecules was evaluated, and the cytotoxicity of these substances in cell lines was evaluated, suggesting possible prototypes of a broad spectrum of components for the treatment of mycoses.

\section{Methods}

2.1. Microorganisms. ATCC strains and clinical isolates belong to the mycology collection of the Laboratory of Clinical Mycology, Department of Clinical Analysis, Faculty of Pharmaceutical Sciences, UNESP, Araraquara, were used in the current study. The strains used were: Candida albicans ATCC 90028, Candida krusei ATCC 6258, Candida parapsilosis ATCC 22019, Candida glabrata ATCC 90030, Candida tropicalis ATCC 750, Cryptococcus neoformans var. grubii ATCC 90012, Histoplasma capsulatum (G217B), Aspergillus niger ATCC 16404, Aspergillus fumigatus ATCC 7100, Trichophyton interdigitalis ATCC 40131. Clinical isolates from Paracoccidioides brasiliensis (18), Trichophyton rubrum and Trichophyton mentagrophytes (102), Cryptococcus neoformans var. grubii resistant to fluconazole (R30), two clinical isolates from Cryptococcus neoformans var. grubii susceptible to fluconazole (S26 and S27), and Cryptococcus gattii (118) isolate from animals, resistant to fluconazole, and Histoplasma capsulatum (M238P) (lung bat) were also used.

2.2. Minimum Inhibitory Concentration (MIC). All microorganisms were tested for susceptibility to specific commercial drugs for the treatment of each gender. The test for yeast was carried out in accordance with the microdilution method described according to the M27-S3 of the CLSI (Clinical and Laboratory Standards Institute) (2008), with modifications. The filamentous fungi susceptibility testing was performed according to the M38-A2 of the CLSI (2008) [9] with modifications to determine the minimum inhibitory concentration (MIC).

Two pure substances extracted from Maytenus ilicifolia, maytenin and pristimerin, were prepared as described byScorzoni et al. 2007 [10]. The antifungal drugs were diluted according to CLSI M27-S3 [9]. Inoculums were prepared in RPMI-1640 (Sigma-Aldrich, St. Louis, MO, USA) with L-glutamine, without sodium bicarbonate, supplemented with $2 \%$ glucose, and buffered to a $\mathrm{pH}$ of 7.0 using 0.165 M MOPS, (Sigma-Aldrich, St. Louis, MO, USA). The yeast suspension was adjusted to a final concentration of $1.0 \times 10^{4} \mathrm{CFU} / \mathrm{mL}$ in RPMI-1640 and for filamentous fungi, a suspension of microconidia was adjusted to 2.5 to $5.0 \times 10^{3}$. In the 96-well plates, substances were added in serial dilutions, starting from a concentration of $250 \mathrm{mg} / \mathrm{L}$ to $0.48 \mathrm{mg} / \mathrm{L}$. The plates were incubated in a shaker at $37^{\circ} \mathrm{C} / 150 \mathrm{rpm}$ to a specific time determined for each microorganism. The reading of MIC was performed by spectrophotometry at $490 \mathrm{~nm}$ and confirmed using Alamar Blue (Sigma-Aldrich, St. Louis, MO, USA).

2.3. Minimum Fungicide Concentration (MFC). A qualitative analysis of fungal viability was performed, by transferring a portion of the wells to a plate with Sabouraud (SigmaAldrich, St. Louis, MO, USA) medium and incubated at $37^{\circ} \mathrm{C}$ during the time determined for each fungal agent. The MFC was determined as the lowest concentration of the extract that did not allow the growth of any fungal colony on the solid medium after the incubation period [11]. A visual reading was performed to confirm the death or growth inhibition provided by the antifungal substances, maytenin and pristimerin.

2.4. Cell Cytotoxicity Assay. The cytotoxicity of maytenin and pristimerin was assessed by MTT for cell lines NOK 
TABLE 1: MIC values and quantitative analysis of fungal cellular viability of pure substances maytenin and pristimerin front of the yeasts and filamentous pathogenic strains causing the most mycoses and evaluation of cytotoxic activity in NOK cells and selectivity index from the ratio of the $\mathrm{IC}_{50}$ and $\mathrm{MFC}$.

\begin{tabular}{|c|c|c|c|c|c|c|}
\hline & $\begin{array}{l}\text { Maytenin } \\
\text { MIC/MFC }\end{array}$ & $\begin{array}{l}\text { Pristimerin } \\
\text { MIC/MFC }\end{array}$ & $\begin{array}{l}\text { Amphotericin } \\
\text { B reference } \\
\text { values MIC }\end{array}$ & $\begin{array}{l}\text { Itraconazole } \\
\text { reference } \\
\text { values MIC }\end{array}$ & $\begin{array}{l}\text { Maytenin } \\
\mathrm{IC}_{50} \\
(\mathrm{mg} / \mathrm{L}) / \mathrm{SI} \\
\end{array}$ & $\begin{array}{l}\text { Pristimerin } \\
\mathrm{IC}_{50} \\
(\mathrm{mg} / \mathrm{L}) / \mathrm{SI}\end{array}$ \\
\hline $\begin{array}{l}\text { Candida albicans ATCC } \\
90028\end{array}$ & $62.50 / 62.50$ & $250.00 / 250.00$ & $0.50-2.00$ & - & $265.7 / 4.25$ & * \\
\hline Candida krusei ATCC 6258 & $15.62 / 62.50$ & $7.81 / 62.50$ & $0.25-2.00$ & $0.12-0.50$ & $78.33 / 1.25^{\star}$ & $24.25 / 0.38$ \\
\hline $\begin{array}{l}\text { Candida parapsilosis ATCC } \\
22019\end{array}$ & $15.62 / 31.25$ & $125.00 / 125.00$ & $0.25-1.00$ & $0.06-0.25$ & $78.33 / 2.50^{\star}$ & $*$ \\
\hline Candida tropicalis ATCC 750 & $15.62 / 31.25$ & $31.25 / 62.52$ & $0.50-2.00$ & - & $78.33 / 2.50 \diamond$ & $203.98 / 3.26 \star$ \\
\hline $\begin{array}{l}\text { Candida glabrata ATCC } \\
90030\end{array}$ & $31.25 / 31.25$ & $125.00 / 125.00$ & $0.25-1.00$ & - & $203.98 / 6.52$ & * \\
\hline $\begin{array}{l}\text { Cryptococcus neoformans } \\
\text { ATCC } 90012\end{array}$ & $0.48 / 0.48$ & $0.97 / 0.97$ & 0.50 & 0.125 & $2.53 / 5.29 \bullet$ & $3.92 / 4.04 \star$ \\
\hline $\begin{array}{l}\text { Cryptococcus neoformans } \\
\text { R30 }\end{array}$ & $3.90 / 3.90$ & $7.81 / 7.81$ & 1.00 & $>32.00$ & $22.18 / 5.68$ & $24.25 / 3.10^{\bullet}$ \\
\hline $\begin{array}{l}\text { Cryptococcus neoformans } \\
\text { isolated } 26\end{array}$ & $0.48 / 0.48$ & $1.95 / 1.95$ & 0.50 & 0.125 & $2.53 / 5.29$ & $6.41 / 3.28$ \\
\hline $\begin{array}{l}\text { Cryptococcus neoformans } \\
\text { isolated } 27\end{array}$ & $0.48 / 0.48$ & $3.90 / 3.90$ & 0.50 & 0.125 & $2.53 / 5.29$ & $20.10 / 5.15$ \\
\hline Cryptococcus gattii 118 & $1.95 / 1.95$ & $3.90 / 3.90$ & 1.00 & $>32.00$ & $9.84 / 5.05^{\star}$ & $20.10 / 5.15^{\star}$ \\
\hline $\begin{array}{l}\text { Paracoccidioides brasiliensis } \\
\mathrm{Pb} 18\end{array}$ & $<0.12 /-$ & $<0.12 /-$ & $0.015-0.25$ & $<0.0039$ & $* *$ & $* *$ \\
\hline $\begin{array}{l}\text { Histoplasma capsulatum } \\
\text { ATCC 0G } 217 \mathrm{~B}\end{array}$ & $0.97 / 0.97$ & $0.48 / 0.48$ & $0.06-0.25$ & $0.25-2.00$ & $3.70 / 3.81 \bullet$ & $6.43 / 13.40$ \\
\hline $\begin{array}{l}\text { Histoplasma capsulatum } \\
\text { isolated } \mathrm{M} 238 \mathrm{P}\end{array}$ & $0.48 / 0.48$ & $0.48 / 0.48$ & $0.06-0.25$ & $0.25-2.00$ & $2.53 / 5.29^{\bullet}$ & $6.43 / 13.40$ \\
\hline $\begin{array}{l}\text { Aspergillus fumigatus ATCC } \\
7100\end{array}$ & $125 /-$ & $>250 /-$ & $0.12-2.0$ & $0.12->16.00$ & * & * \\
\hline $\begin{array}{l}\text { Aspergillus niger ATCC } \\
16404\end{array}$ & $0.97 / 0.97$ & $250 / 250$ & $0.12-0.5$ & $0.12-1.00$ & - $3.70 / 3.81$ & * \\
\hline $\begin{array}{l}\text { Trichophyton rubrum clinical } \\
\text { isolated }\end{array}$ & $1.95 / 1.95$ & $250 / 250$ & - & $0.03-4.00$ & 9.84/5.05 & * \\
\hline $\begin{array}{l}\text { Trichophyton mentagrophytes } \\
\text { ATCC } 40131\end{array}$ & $3.9 / 3.9$ & $62.5 / 250$ & - & $0.03-0.25$ & -22.18/5.68 & $150.24 / 0.6$ \\
\hline $\begin{array}{l}\text { Trichophyton mentagrophytes } \\
\text { clinical isolated } 102\end{array}$ & $3.9 / 3.9$ & $125 / 250$ & - & $0.03-0.25$ & • $22.18 / 5.68$ & * \\
\hline
\end{tabular}

MIC: minimum inhibitory concentration; MFC: minimum fungicide concentration.

- $\mathrm{IC}_{50} / \mathrm{IS}$ values in NOK cells.

* $\mathrm{IC}_{50} / \mathrm{IS}$ not apply because the MIC and MFC values are above $62.5 \mathrm{mg} / \mathrm{L}$.

** $\mathrm{IC}_{50} / \mathrm{IS}$ not apply because the MIC and MFC values are below $0.12 \mathrm{mg} / \mathrm{L}$.

$\mathrm{IC}_{50}: 50 \%$ inhibitory concentration. SI: selectivity index obtained from the relationship between the $\mathrm{IC}_{50}$ (NOK) by MFC for each fungi.

(keratinocyte oral mucosa), obtained from the American Type Culture Collection (Manassas, VA, USA). The cells were grown in own culture medium NOK (Keratinocytes-SFM, GIBCO), and maintained at $36.5^{\circ} \mathrm{C}$. A concentration ranging from 2.5 to $5.0 \times 10^{4}$ cells $/ \mathrm{mL}$ was used for the formation of monolayer cells. The concentrations of pure substances were kept in contact with the cells for 24 hours. After the incubation period, the cells treated with the MTT reagent has an additional $5 \mathrm{mg} / \mathrm{mL}$ added, (Sigma-Aldrich, St. Louis, MO, USA) and the cells were incubated again for another $4 \mathrm{~h}$. After the formation of formazan crystals, $100 \mu \mathrm{L}$ of isopropanol was added to solubilize the precipitate and allow the reading of the result by changing the color of the medium
[12]. The absorbance of formazan was quantified using an ELISA reader (enzyme-linked immunosorbent assay) set at $560 \mathrm{~nm}$. As a positive control test, hydrogen peroxide was used.

\section{Results}

3.1. Minimum Inhibitory Concentration (MIC). Table 1 present the results of the antifungal activity of maytenin and pristimerin, isolated from Maytenus ilicifolia. Maytenin activity was classified as potent for both yeasts and for filamentous fungi, when compared to positive controls itraconazole and amphotericin B; since the MIC ranged 
between 0.12 and $62.5 \mathrm{mg} / \mathrm{L}$. Pristimerin previously showed a significant variation in the action potential. For yeasts, the pristimerin showed potent activity, with the exception of $C$. glabrata ATCC 90030 which showed moderate activity and $C$. albicans ATCC 90028, which presented low antifungal activity. For the filamentous fungi, pristimerin showed moderate activity, with the exception of Trichophyton mentagrophytes ATCC 40131, which showed a MIC of $62.5 \mathrm{mg} / \mathrm{L}$ and was classified as having potent activity.

3.2. Minimum Fungicide Concentration (MFC). Minimum fungicide concentration was performed to confirm cell death in MIC through observation of no colony growth in a rich medium. The maytenin showed fungicide activity for most yeasts. No growth of $C$. albicans colonies was observed, and the death of yeast occurred in a higher dilution concentration (Table 1). For the filamentous fungi, MFC was confirmed by testing cell viability, which occurs in MIC fungal cell death (Table 1).

Pristimerin presented a greater difference between the MIC and MFC. Moreover, the difference between the MIC and the value of qualitative analysis of fungal viability was greater than the difference presented by maytenin (Table 1).

For the fungus Paracoccidioides brasiliensis and the filamentous fungi Aspergillus niger and fumigatus, the qualitative test of fungal viability was flawed, since the growth of colonies cannot be observed on a solid medium.

3.3. Cell Cytotoxicity Assay. The cytotoxicity assay for the NOK cell line showed more than $80 \%$ of cell viability in MIC maytenin concentrations. The substance pristimerin showed cell viability above $80 \%$ in normal cells (Table 1 ).

\section{Discussion}

Plants have been used in medicine for a long period of time, since they are easy to obtain and apply various diseases $[4,13]$. Regarding the search for new antifungal agents, the ideal must have a broad spectrum of fungicidal activity without causing toxicity to the host [14]. The treatment of fungal infections is not always effective because of resistance to drugs in addition to presenting high toxicity for human cells. For this reason, there is a continuing search for new drugs which are more potent antifungal, but safer, than existing drugs [15].

The present study showed that pristimerin and maytenin had potente action on the fungi studied (Table 1), but maytenin showed the best results. The exception was Histoplasma capsulatum isolated M238P and Paracoccidioides brasiliensis which showed MIC equal for both substances.

Alanís-Garza et al., 2007 [16] studied the antiHistoplasma activity of extracts obtained from various plants and showed MICs between 16 and $125 \mathrm{mg} / \mathrm{L}$. This study showed an MIC for ATCC strains of H. capsulatum 0.97 and less than $0.48 \mathrm{mg} / \mathrm{L}$ pristimerin and maytenin respectively, while for clinical isolate, the MIC for the two substances was less than a $0.48 \mathrm{mg} / \mathrm{L}$. Compared with few literary data of natural products active against this fungal, pristimerin and maytenin can be considered prototypes that are excellent anti-Histoplasma.

Few studies have searched for new drugs from natural products for $P$. brasiliensis [17, 18]. There are reports of the activity of anti-Paracoccidioides of Piper regnellii and "Baccharis dracunulifolia" $30 \mathrm{mg} / \mathrm{L}$ [17, 19]. The results expressed in this study were excellent for P. brasiliensis, MIC of $0.12 \mathrm{mg} / \mathrm{L}$ for both molecules at a concentration 65 times lower than the results of the studies mentioned above.

The systemic mycosis caused by yeasts Cryptococcus spp. has increased because of AIDS [20]. In the current results indicate that the molecules had an excellent MIC for the yeasts this genus, ranging from 0.48 to $3.9 \mathrm{mg} / \mathrm{L}$ for maytenin and 0.97 to 7.8 for pristimerin. Another study revealed the antifungal activity of extracts of Maytenus undata against $C$. neoformans, which showed MIC of $0.09 \mathrm{mg} / \mathrm{L}$ after $24 \mathrm{~h}$, and $0.18 \mathrm{mg} / \mathrm{L}$ after $48 \mathrm{~h} \mathrm{[21].} \mathrm{The} \mathrm{species} \mathrm{Candida} \mathrm{are} \mathrm{classified}$ as the fourth most common pathogen in hospitals and are associated with increased mortality of bloodstream infections due to these fungi having high resistance to existing antifungal [22]. For this yeast, the pristimerin showed potent activity, with the exception of C. glabrata ATCC 90030, which showed moderate activity, and $C$. albicans ATCC 90028, which obtained low antifungal activity. Maytenin showed moderate antifungal activity for this specie. For C. albicans, maytenin and pristimerin showed fungicide activity; however, the Candida non-albicans the result was fungistatic, except for C. glabrata in contact pristimerin.

Although dermatophyte infections are restricted to certain areas of the epidermis, they can be invasive and cause serious injury [23]. Due to the high incidence there is a great need to find new drugs which act on the dermatophytes. Maytenin showed potent activity with MIC ranging from 1.95 to $3.9 \mathrm{mg} / \mathrm{L}$. For filamentous fungi, the pristimerin showed moderate activity, with the exception of Trichophyton mentagrophytes ATCC 44131, which showed a MIC of $62.5 \mathrm{mg} / \mathrm{L}$. Many studies have demonstrated the plant antifungal potential against these dermatophytes [2325], as the study of Lau et al. 2010 [24], that evaluated extracts Eucalypti Folium and Fructus Psoraleae Globuli. Both the pure compounds effectively inhibit the growth of $T$. mentagrophytes and T. rubrum [25].

Invasive aspergillosis is an important cause of mortality in transplant patients [26]. Maytenin had better results against Aspergillus niger with an MIC value of $0.97 \mathrm{mg} / \mathrm{L}$, whereas the MIC for A. fumigatus was $125 \mathrm{mg} / \mathrm{L}$ and pristimerin was similar for both $250 \mathrm{mg} / \mathrm{L}$. Maytenin showed good fungicide activity for most filamentous fungi, while pristimirin showed high MIC (Table 1).

On the other hand, the cytotoxicity tests performed with NOK (keratinocytes oral mucosa) showed that the experimental substances are not cytotoxic to this cell examined in experiment (Table 1). Although most of the antifungal agents available on the market are of synthetic origin, natural products of the study received the attention of researchers, mainly, due to the occurrence of unwanted factors, such as the resistance of some strains the conventional antifungal agents-especially in immunocompromised individualsand the presence of these toxic effects. Figueiredo et al. (1998) 
found antimalarial activity of various substances, including the pristimerin but the cytotoxicity was only for the 17(methoxycarbonyl)-28-nor-isoiguesterin in adenocarcinoma cell line HT-29 [27].

With respect to selectivity index (SI), it is known that the higher the SI of a substance, the greater is its security. In our study we found that the maytenin substance had SI above 1.0 for all species tested, so we can demonstrate the safe use of this. Likewise, the pristimerin presented high SI against some fungal species, as described for $H$. capsulatum (SI 13.40). However, when comparing the two substances, maytenin still showed better results (Table 1).

\section{Conclusion}

The results of this study indicate the potential use of maytenin and pristimerin for the treatment of fungal infections, which showed a potent antifungal activity against the fungi studied. Therefore, the data obtained are promising. Although the medicinal plant "Maytenus ilicifolia" is consolidated in the treatment of gastritis and ulcers more pharmacological studies will be necessary to evaluate these molecules as antifungal prototypes.

\section{Acknowledgments}

The authors are grateful to the Fundação de Amparo Pesquisa do Estado de São Paulo (FAPESP) and the Conselho Nacional de Desenvolvimento Científico and Tecnológico (CNPq) for their financial support. V. Santos thanks CAPES and is also grateful to Pró-Reitoria de Pesquisa (PROPe/UNESP) for providing a research fellowship.

\section{References}

[1] S. Shoham and S. M. Levitz, "The immune response to fungal infections," British Journal of Haematology, vol. 129, no. 5, pp. 569-582, 2005.

[2] M. A. Shikanai-Yasuda, F. D. Q. Telles Filho, R. P. Mendes et al., "Guideliness in paracoccidioidomycosis," Revista da Sociedade Brasileira de Medicina Tropical, vol. 39, no. 3, pp. 297-310, 2006.

[3] H. Hostettman, Strategy of the biological and chemical evaluation of plant extracts, vol. 70, IUPAC, 1998.

[4] J. C. O. Sardi, A. M. F. Almeida, and M. J. S. Mendes Giannini, "New antimicrobial therapies used against fungi present in subgingival sites - a brief review," Archives of Oral Biology, vol. 56, no. 10, pp. 951-959, 2011.

[5] M. C. T. Duarte, G. M. Figueira, A. Sartoratto, V. L. G. Rehder, and C. Delarmelina, "Anti-Candida activity of Brazilian medicinal plants," Journal of Ethnopharmacology, vol. 97, no. 2, pp. 305-311, 2005.

[6] R. Santos-Oliveira, S. Coulaud-Cunha, and W. Colaço, "Review of Maytenus ilicifolia Mart. ex Reissek, Celastraceae. Contribution to the studies of pharmacological properties," Brazilian Journal of Pharmacognosy, vol. 19, no. 2B, pp. 650659, 2009.

[7] V. A. De Freitas Formenton Macedo Dos Santos, D. P. Dos Santos, I. Castro-Gamboa, M. V. B. Zanoni, and M. Furlan,
"Evaluation of antioxidant capacity and synergistic associations of quinonemethide triterpenes and phenolic substances from maytenus ilicifolia (celastraceae)," Molecules, vol. 15, no. 10, pp. 6956-6973, 2010.

[8] L. de León, M. R. López, and L. Moujir, "Antibacterial properties of zeylasterone, a triterpenoid isolated from Maytenus blepharodes, against Staphylococcus aureus," Microbiological Research, vol. 165, no. 8, pp. 617-626, 2010.

[9] Clinical Laboratory Standard Institute (CLSI), Document M38-A2. Reference method for broth dilution antifungal susceptibility testing of filamentous fungi, Clinical Laboratory Standard Institute (CLSI), Wayne, Pa, USA, 2nd edition, 2008.

[10] L. Scorzoni, T. Benaducci, A. M. Fusco-Almeida, D. H. S. Silva, V. S. Bolzani, and M. J. S. Mendes-Giannini, "The use of standard methodology for determination of antifungal activity of natural products against medical yeasts Candida sp and Cryptococcus sp.," Brazilian Journal Microbiological, vol. 38, no. 3, pp. 391-397, 2007.

[11] L. O. Regasini, M. Pivatto, L. Scorzoni et al., "Antimicrobial activity of Pterogyne nitens Tul., Fabaceae, against opportunistic fungi," Brazilian Journal of Pharmacognosy, vol. 20, no. 5, pp. 706-711, 2010.

[12] T. Mosmann, "Rapid colorimetric assay for cellular growth and survival: application to proliferation and cytotoxicity assays," Journal of Immunological Methods, vol. 65, no. 1-2, pp. 55-63, 1983.

[13] J. J. Rojas, V. J. Ochoa, S. A. Ocampo, and J. F. Muñoz, "Screening for antimicrobial activity of ten medicinal plants used in Colombian folkloric medicine: a possible alternative in the treatment of non-nosocomial infections," BMC Complementary and Alternative Medicine, vol. 6, article no. 2, 2006.

[14] A. J. Carrillo-Muñoz, G. Giusiano, P. A. Ezkurra, and G. Quindós, "Antifungal agents: mode of action in yeast cells," Revista Espanola de Quimioterapia, vol. 19, no. 2, pp. 130-139, 2006.

[15] R. Fenner, A. H. Betti, L. A. Mentz, and S. M. K. Rates, "Plants with potencial antifungal activity employed in Brazilian folk medicine," Brazilian Journal of Pharmaceutical Sciences, vol. 42, no. 3, pp. 369-394, 2006.

[16] B. A. Alanís-Garza, G. M. González-González, R. SalazarAranda, N. Waksman de Torres, and V. M. Rivas-Galindo, "Screening of antifungal activity of plants from the northeast of Mexico," Journal of Ethnopharmacology, vol. 114, no. 3, pp. 468-471, 2007.

[17] S. Johann, N. P. Sá, L. A. Lima et al., "Antifungal activity of schinol and a new biphenyl compound isolated from Schinus terebinthifolius against the pathogenic fungus Paracoccidioides brasiliensis," Annals of Clinical Microbiology and Antimicrobials, vol. 9, article 30, 2010.

[18] L. de Carvalho Tavares, S. Johann, T. Maria de Almeida Alves et al., "Quinolinyl and quinolinyl N-oxide chalcones: synthesis, antifungal and cytotoxic activities," European Journal of Medicinal Chemistry, vol. 46, no. 9, pp. 4448-4456, 2011.

[19] C. V. Martins, D. L. da Silva, A. T. Neres et al., "Curcumin as a promising antifungal of clinical interest," Journal of Antimicrobial Chemotherapy, vol. 63, no. 2, pp. 337-339, 2009.

[20] Md. Saúde, "Dados e pesquisas em DST e AIDS," DST/AIDS CPNd editor. Brasilia, Brasil, 2002.

[21] T. A. Mokoka, L. J. McGaw, and J. N. Eloff, "Antifungal efficacy of ten selected South African plant species against Cryptococcus neoformans," Pharmaceutical Biology, vol. 48, no. 4, pp. 397-404, 2010.

[22] T. Rossignol, B. Kelly, C. Dobson, and C. d'Enfert, "Endocytosis-mediated vacuolar accumulation of the human 
ApoE apolipoprotein-derived ApoEdpL-W antimicrobial peptide contributes to its antifungal activity in Candida albicans," Antimicrobial Agents and Chemotherapy, vol. 55, no. 10, pp. 4670-4681, 2011.

[23] N. T. Peres, F. C. A. Maranhão, A. Rossi, and N. M. Martinez-Rossi, "Dermatophytes: host-pathogen interaction and antifungal resistance," Anais Brasileiros de Dermatologia, vol. 85, no. 5, pp. 657-667, 2010.

[24] K. M. Lau, L. H. Fu, L. Cheng et al., "Two antifungal components isolated from fructus psoraleae and folium eucalypti globuli by bioassay-guided purification," American Journal of Chinese Medicine, vol. 38, no. 5, pp. 1005-1014, 2010.

[25] C. Cavaleiro, M. J. Gonçalves, D. Serra et al., "Composition of a volatile extract of Eryngium duriaei subsp. juresianum (M. Laínz) M. Laínz, signalised by the antifungal activity," Journal of Pharmaceutical and Biomedical Analysis, vol. 54, no. 3, pp. 619-622, 2011.

[26] M. C. Z. Novaretti, A. S. Ruiz, F. L. Dulley, P. E. DorlhiacLlacer, and D. A. F. Chamone, "Detection of Aspergillus sp in bone marrow transplant patients by PCR-nested technique," Revista Brasileira de Hematologia e Hemoterapia, vol. 30, no. 2, pp. 162-163, 2008.

[27] J. N. Figueiredo, B. Räz, and U. Séquin, "Novel quinone methides from Salacia kraussii with in vitro antimalarial activity," Journal of Natural Products, vol. 61, no. 6, pp. 718723, 1998. 


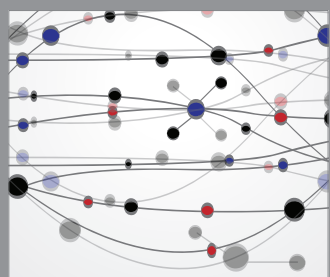

The Scientific World Journal
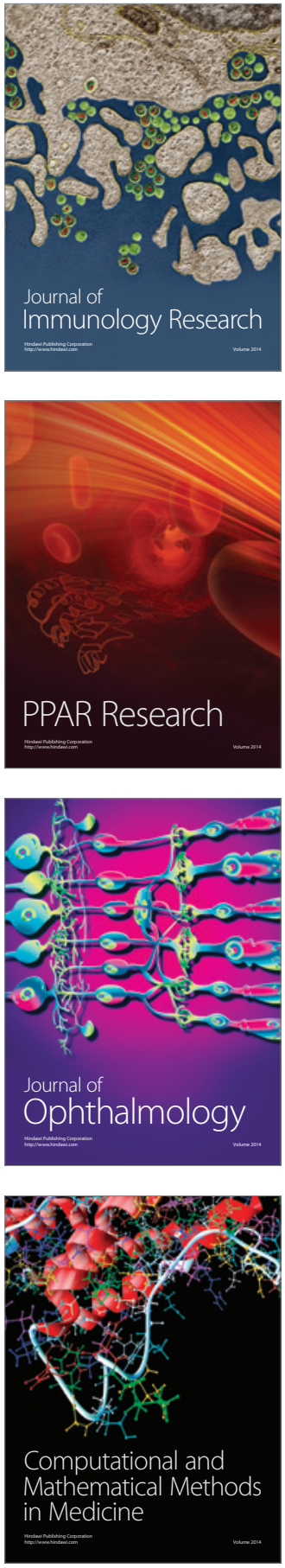

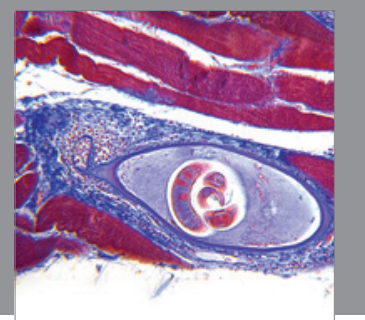

Gastroenterology

Research and Practice
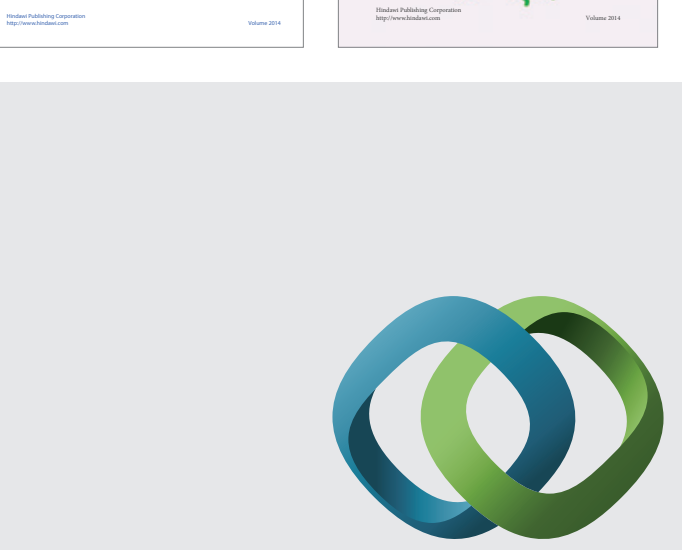

\section{Hindawi}

Submit your manuscripts at

http://www.hindawi.com
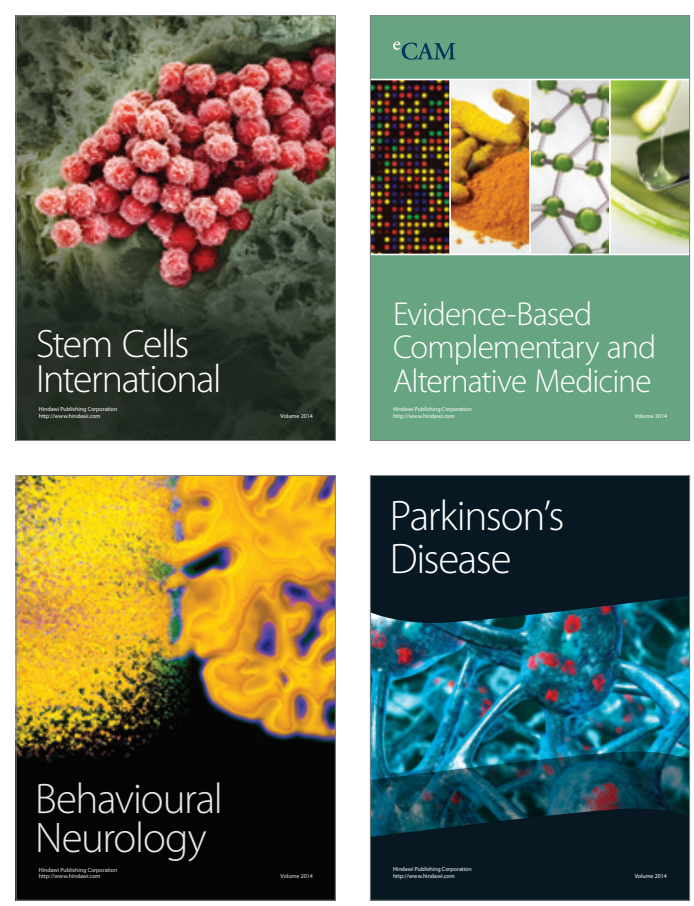

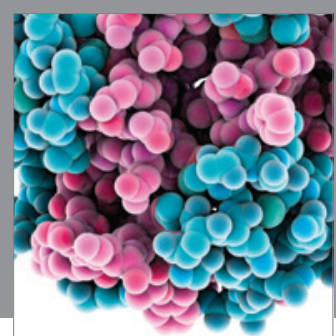

Journal of
Diabetes Research

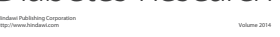

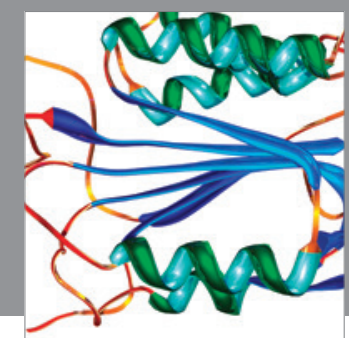

Disease Markers
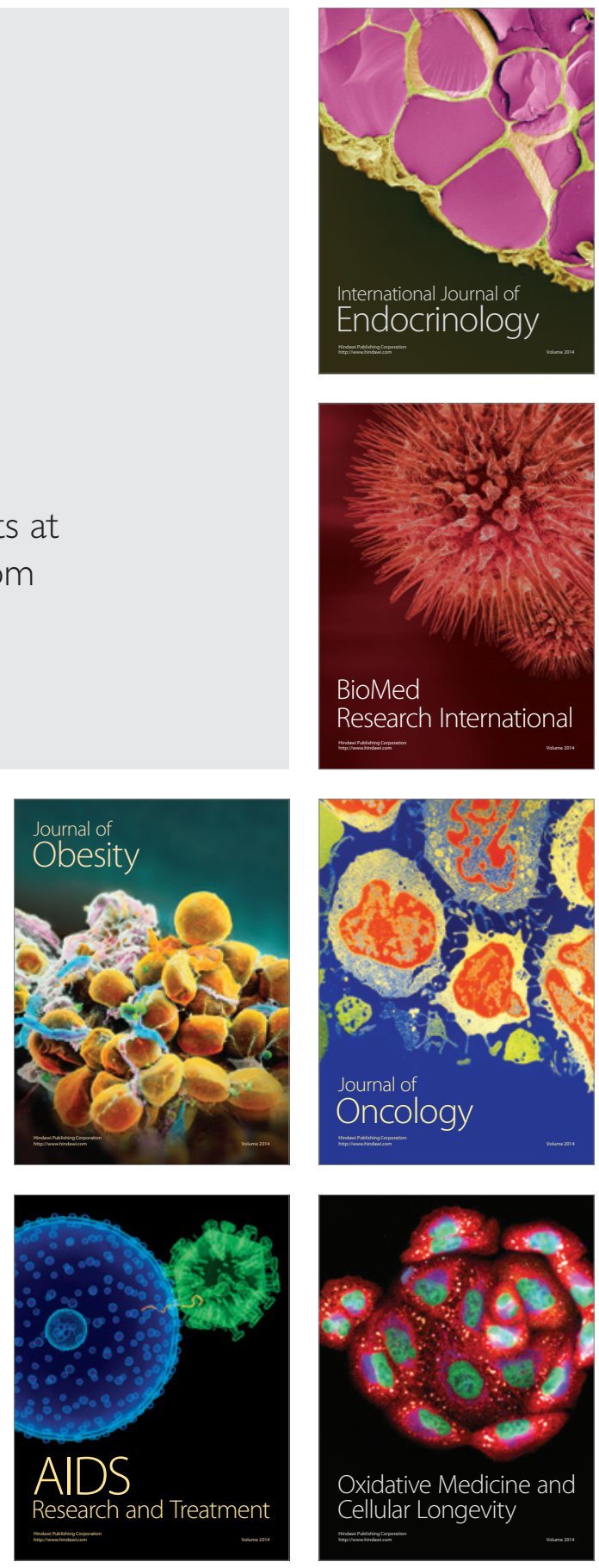